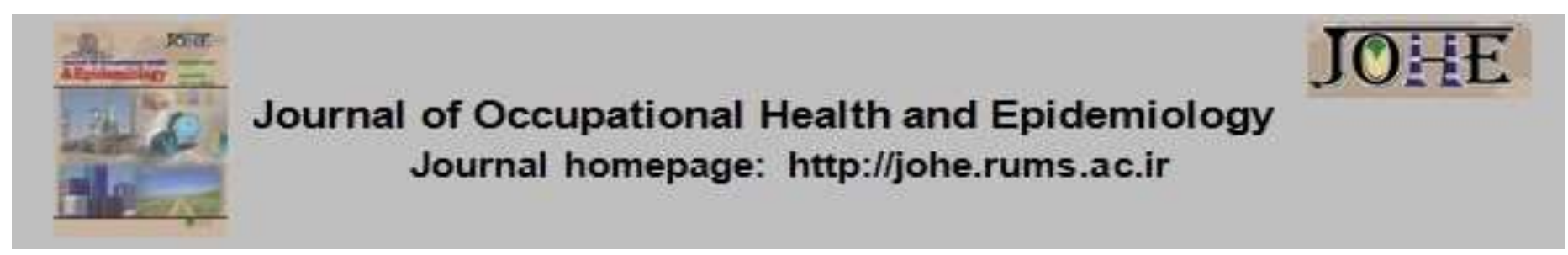

\title{
Quality of work life and its association with job burnout and job performance among Iranian healthcare employees in Islamabad-e Gharb, 2016
}

\author{
Ehsan Bakhshi ${ }^{*}$, Faramarz Gharagozlou², Ali Moradi $^{3}$, Mohammad Reza Naderi ${ }^{4}$
}

1- MSc of Ergonomics, Health Center, Islamabad-e-Gharb Health Network, Kermanshah University of Medical Science, Kermanshah, Iran.

2- Assistant Prof., Department of Occupational Health, School of Public Health, Kermanshah University of Medical Science, Kermanshah, Iran.

3- Faculty of Humanities, Kermanshah Branch, Islamic Azad University, Kermanshah, Iran.

4- Medical Doctor, Islamabad-e-Gharb Health Network, Kermanshah University of Medical Sciences, Kermanshah, Iran.

Article Info

* Corresponding author:

Ehsan Bakhshi,

E-mail:

Ehsanbakhshi63@gmail.com

\section{Article history}

Received: Dec, 2018

Accepted: Mar, 2019

10.29252/johe.8.2.94

Print ISSN: 2251-8096 Online ISSN: 2252-0902

Peer review under responsibility of Journal of Occupational Health and Epidemiology
Citation: Bakhshi E, Gharagozlou F, Moradi A, Naderi MR. Quality of work life and its association with job burnout and job performance among Iranian healthcare employees in Islamabad-e Gharb, 2016. JOHE 2019; 8(2):94-101.

\section{Introduction}

Health organizations play an important role in the maintenance and development of health in human societies (1) while the fulfillment of this objective requires a healthy and highly motivated workforce (2).

Quality of work life refers to the conceptions and thoughts that employees have about their job, the extent to which they are satisfied with their job, and the way they consider their job relative to their goals
(3). In the unfavorable quality of work life, dissatisfaction and maladjusted behavior may arise among personnel. By contrast, high quality of work life leads to a climate of trust and mutual respect, in which employees can be active and develop their psychological as well as reducing the rigid control mechanisms in organization (4). Quality of work life contains two basic concepts in its definition. First, it includes a subjective concept and, second, it has a multidimensional structure. In terms of dimensions, 
it includes the physical, psychological, and environmental factors that compare the desires and needs of individuals between what they should have and what is available (5). The concept of quality of work life is currently related to a philosophy in the organizations that seek to increase employees' dignity. In some organizations, managers aim to enhance employees' trust, engagement, and problem-solving skills by implementing appropriate quality of work life plans and, thereby, to enhance organizational satisfaction and effectiveness (6). .These plans and programs will exert significant impacts on employee's behavioral responses such as job satisfaction, work participation, job performance, intention for job resignation, and organizational change and transformation (7). Hood \& Smith believe that of managers' close attention to quality of work life variables can facilitate a more humanistic work environment, which not only addresses the basic needs of employees but also encompasses the needs of higher levels, continuous growth, and improved performance (8). Much attention has been recently drawn to QWL as an approach to balancing job burnout (9).

Job burnout arises from the response to long-term stress in the workplace, and this syndrome is related to the workplace, in which one's attitudes towards efforts and endeavors in the workplace are negatively affected (10). People with burnout often suffer from headaches, sleep disorder, irritable mood, anxiety, depression, and hypertension (11). Job burnout reduces cognitive ability and, hence, results in reduced job satisfaction and increased disorder in organizational commitment as well as personal injury (12). The imbalance between expectations, knowledge, and skills of employees on one hand, and job requirements, job resources, and responsibilities on the other hand lead to burnout. In addition, high workload and the lack of social support are among the other major risk factors for this phenomenon (13). Since job burnout creates a negative attitude toward the job and a sense of disconnection with the patient during care delivery, it leads to a serious loss of quality of healthcare services; therefore, a careful identification of more effective factors in this area will be beneficial for improving the quality of services provided in the field of health and treatment (14). In addition to job burnout, quality of work life could also have impact on job performance of employees.

Job performance has a significant association with an organization's goals, and it is necessary for the organization to pay special attention to it (15). Job performance refers a set of behaviors controlled by individuals, which affect the goals of the employing organization. The main key to the development and improvement of job performance of individuals is the identification of the various organizational factors that influence individuals' performance (16). The employees' attitude towards different organizational issues, especially towards the job and the profession they perform, as well as promotions, assigned tasks, selection for training, and pay raise based on assessment can play an important role in increasing their motivation and cause them to perform their duties and responsibilities in the best way, which, in turn, leads to an increase in the effectiveness and efficiency of the organization (17, 18). Today, healthcare organizations are in need of strong support on part of managers in terms of performance evaluation. Performance measurement is one of the most important strategic processes that determines the extent to which the goals and plans of an organization are fulfilled inasmuch as the enhancement of accountability and responsiveness (19). Regarding the role of health staff in the quality of service delivery, it can be argued that the progress and enhancement of an organization hinges upon the employees, who must be aware of the quality of care in their organization. With regard to the important role of staff of health centers and public health centers in the maintenance of people's health, this study aimed to evaluate quality of work life and its effect on burnout and job performance.

\section{Materials and Methods}

In the beginning, this project was approved by the Vice Chancellor of Research Affairs at Kermanshah University of Medical Sciences, Iran (ID code: IR.KUMS.REC.1397.988).

This cross-sectional, descriptive study was conducted based on the census methods at the healthcare centers in Islamabad-e Gharb in 2016. In total, 180 questionnaires were distributed among the participants, and 136 questionnaires were completed and returned (response rate: $75 \%$ )

In this study, the following four questionnaires were used:

A demographic characteristics questionnaire: It included information about age, gender, marital status, work experience, education level, history of smoking, place of employment, and employment status.

Walton's Quality of Work Life Questionnaire: This questionnaire is constructed based on Walton's components (20). The reliability of the questionnaire was reported by Ghaleei et al. to be 0.78 (21). This questionnaire includes such components as adequate and fair compensation, safe healthy working environment, opportunity for continued growth and security, constitutionalism in the work organization, social relevance of work life, social 
integration and cohesiveness, and the development of human capacities. The questionnaire items are scored based on a five-point, qualitative Likert scale (very low $=1$, low $=2$, moderate $=3$, high $=4$, very high = 5). The scores can range from 32 to 160 , where scores lower than 74 are considered as low, 75 to 117 as moderate, and those higher than 118 are known as high.

Maslach Burnout Inventory: This questionnaire is one of the most common tools used for the measurement of burnout, which consists of 22 statements. It was designed by Maslach and measures three dimensions of job burnout (22). where nine items pertain to emotional exhaustion, five items relate to depersonalization, and eight statements are about personal accomplishment. The reliability and validity of this questionnaire were confirmed in Iran for the first time by Filian, who reported a test-retest reliability index of 0.78 (23). for the questionnaire. The total score range for total job burnout varies between 0 and 132, in which the scores below 44 ( $\leq 44)$ represent low job burnout, 45 to 89 show moderate job burnout, and those higher than $99(\geq 90)$ indicate high job burnout. Hersey and Goldsmith's Job Performance Questionnaire: This questionnaire, developed by Hersey and Goldsmith, consists of 16 questions under seven components including ability, clarity of role, support, motivation, feedback, validity, and environment. The validity and reliability of this questionnaire were confirmed by Ardestani et al. with a Cronbach's alpha of 0.86 (24). The Cronbach's alpha reliability of this scale was calculated to be 0.75 in the present study. The scores are classified into three ranges: 16-37, 3758 , and 59-80 representing low, moderate, and high job performances, respectively.

The obtained data were analyzed using descriptive statistics, the spearman correlation coefficient, independent t-tests, and one-way ANOVAs at a confidence level of 0.95 in version 19 of the SPSS software.

\section{Results}

In this study, $48.52 \%$ of the participants were male. The mean and standard deviation of the participants' age was $36.4 \pm 8.1$ years old. Table 1 shows the demographic characteristics of the staff in healthcare centers and health homes.

Table 1: The demographic characteristics of the staffs in healthcare centers and health homes

\begin{tabular}{|c|c|c|c|}
\hline & & $\mathbf{N}$ & $\%$ \\
\hline \multirow{2}{*}{ Sex } & Male & 66 & 48.52 \\
\hline & Female & 70 & 51.48 \\
\hline \multirow{2}{*}{ Marital status } & Married & 27 & 19.85 \\
\hline & No married & 109 & 80.15 \\
\hline \multirow{4}{*}{ Education level } & Less than diploma & 18 & 13.23 \\
\hline & Diploma & 39 & 28.67 \\
\hline & Associates degree & 27 & 18.85 \\
\hline & Bachelor degree & 52 & 39.25 \\
\hline \multirow{3}{*}{ Age groups } & Under 30 & 22 & 16.17 \\
\hline & $31-40$ & 55 & 40.53 \\
\hline & 41 and older & 59 & 43.30 \\
\hline \multirow{3}{*}{ Years of service } & $1-10$ years & 55 & 40.44 \\
\hline & $11-20$ years & 52 & 38.24 \\
\hline & $21-30$ years & 29 & 21.32 \\
\hline \multirow{3}{*}{ Type of employment } & Contractual & 26 & 19.11 \\
\hline & Employment contract & 28 & 20.58 \\
\hline & Permanent & 82 & 60.29 \\
\hline \multirow{2}{*}{ Job category } & Health center & 77 & 56.61 \\
\hline & Health house & 59 & 43.38 \\
\hline \multirow{2}{*}{ Cigarette smoking } & Yes & 12 & 9 \\
\hline & No & 124 & 91 \\
\hline
\end{tabular}

In this research, the most experienced QWL level (72\% of the participants) was at moderate, followed by low (26\%). The mean and standard deviation of job burnout, job performance, and quality of work life were $45.95 \pm 17.77,52.5 \pm 9$, and $73.91 \pm 13.22$, respectively. Table 2 illustrates the mean and standard deviation of all components of QWL, job performance and job burnout in staff of healthcare centers and health homes. 
Table 2: Mean and standard deviation of QWL, job performance, job burnout and their aspects

\begin{tabular}{lcc}
\hline \multicolumn{1}{c}{ Variable } & Mean \pm SD & Range of score \\
\hline Quality of work life: & $76.91 \pm 13.25$ & $32-160$ \\
\hline -Adequate and fair compensation & $10 \pm 2.80$ & $5-25$ \\
\hline -Safe and healthy working conditions & $7.61 \pm 2.10$ & $3-15$ \\
\hline -Opportunity for continued growth and security & $7.50 \pm 2.41$ & $3-15$ \\
\hline -Organizational legality & $14 \pm 4.92$ & $6-30$ \\
\hline -Social relevance of work life & $8 \pm 2.51$ & $3-15$ \\
\hline -Work and the total life span & $11.12 \pm 3.15$ & $5-25$ \\
\hline -Social integration in the work organization & $8.70 \pm 2.31$ & $4-20$ \\
\hline -Developing human capabilities & $9.71 \pm 2.82$ & $3-15$ \\
\hline Job burnout: & $45.95 \pm 17.77$ & $0-132$ \\
\hline -Emotional Exhaustion & $21.23 \pm 11.93$ & $0-54$ \\
\hline -Depersonalization & $4.64 \pm 4.22$ & $0-30$ \\
\hline -Personal Accomplishment & $30.17 \pm 8.26$ & $0-48$ \\
\hline -Ability & $52.51 \pm 9$ & $16-80$ \\
\hline -Clarity & $10.90 \pm 2.31$ & $3-15$ \\
\hline -Help & $7.82 \pm 1.32$ & $2-10$ \\
\hline -Incentive & $5.91 \pm 2$ & $2-10$ \\
\hline -Evaluation & $8.92 \pm 2.41$ & $3-15$ \\
\hline -Validity & $5.62 \pm 2$ & $2-10$ \\
\hline -Environment & $6.62 \pm 1.93$ & $2-10$ \\
\hline
\end{tabular}

The Pearson correlation coefficient showed that quality of work life had a significant negative correlation with job burnout $(p$-value $=0.001)$ but a significant positive correlation with job performance ( $p$-value $=0.001)$. Moreover, there was a significant negative association between job burnout and job performance $(p$-value $=0 / 01)$. All components of quality of work life, with the exception of the overall work environment, had a significant effect on job performance ( $p$-value $\leq 0.05$ ). Similarly, job burnout was significantly influenced by all components of quality of work life, except for social integration $(p-$ value $\leq 0.05$ ) (table 3$)$.

Table 3: Association between aspects of quality of work life with job performance and job burnout

\begin{tabular}{lcc}
\hline \multicolumn{1}{c}{ Dimensions of quality of work life } & Job performance & Job burnout \\
\cline { 2 - 3 } & $\mathrm{r}$ & $\mathrm{r}$ \\
\hline Adequate and fair compensation & $0.397^{* *}$ & $-0.281^{* *}$ \\
\hline Safe and healthy working environment & $0.336^{* *}$ & $-0.184^{*}$ \\
\hline Growth and security & $0.479^{* *}$ & $-0.205^{*}$ \\
\hline Organizational legality & $0.675^{* *}$ & $-0.282^{* *}$ \\
\hline Social relevance of work life & $0.533^{* *}$ & $-0.192^{*}$ \\
\hline Work and the total life span & -0.087 & $0.233^{*}$ \\
\hline Social integration in the work organization & $0.561^{* *}$ & -0.085 \\
\hline Developing human capabilities & $0.537^{* *}$ & $-0.224^{*}$ \\
\hline Quality of work life & $0.642^{* *}$ & $-0.291^{* *}$ \\
\hline Job burnout & $-0.242^{* *}$ & - \\
\hline Spearman correlation efficiencies level of significant: $p \leq 0.05 \quad p<0.001^{* *}$ & $p<0.050^{*}$ &
\end{tabular}

The Pearson correlation coefficient showed that quality of work life had a significant effect on all components of job performance except the work environment. In addition, quality of work life was significantly correlated with emotional exhaustion (p-value $\leq 0.05$ ) (Table 4).

Table 4: Association of quality of work life with aspects of job performance and job burnout

\begin{tabular}{|c|c|}
\hline & Quality of work life \\
\hline Job performance: & $0.642^{\star \star}$ \\
\hline -Ability & $0.307^{* \star}$ \\
\hline -Clarity & $0.423^{\star \star}$ \\
\hline -Help & $0.651^{\star \star}$ \\
\hline -Incentive & $0.538^{* *}$ \\
\hline -Evaluation & $0.571^{\star *}$ \\
\hline -Validity & $0.506^{\star *}$ \\
\hline -Environment & -0.070 \\
\hline Job burnout: & $-0.291^{\star *}$ \\
\hline -Emotional Exhaustion & $-0.329^{* *}$ \\
\hline -Depersonalization & -0.069 \\
\hline -Personal Accomplishment & $-0.136^{*}$ \\
\hline
\end{tabular}

Spearman correlation coefficients level of significant: $p \leq 0.05 \quad p<0.001^{* *} \quad p<0.050^{*}$


The one-way analysis of variance (ANOVA) showed that job performance and quality of work life were correlated with educational level ( $p$-value $<0.05$ ). An independent t-test revealed a significant association between job performance and gender $(p$-value $=$ 0.04). Table 5 shows the association between quality of work life, job performance, and job burnout with demographic and contextual variables.

Table 5: Association between quality of work life, job performance, and job burnout with demographic and contextual variables

\begin{tabular}{lcccc}
\hline Variables & $\begin{array}{c}\text { Job } \\
\text { performance }\end{array}$ & $\begin{array}{c}\text { Quality of work } \\
\text { life }\end{array}$ & Job burnout & Type of test \\
\hline Age groups & 0.70 & 0.11 & 0.21 & ANOVA \\
\hline Sex & $0.04^{*}$ & 0.31 & 0.355 & T-TEST \\
\hline Married status & 0.90 & 0.66 & 0.29 & T-TEST \\
\hline Type of employment & 0.91 & 0.3 & 0.71 & ANOVA \\
\hline Education & $0.004^{*}$ & $0.003^{*}$ & 0.92 & ANOVA \\
\hline Years of work & 0.31 & 0.36 & 0.31 & ANOVA \\
\hline
\end{tabular}

\section{Discussion}

The results of this study showed that the quality of work life is inversely related to job burnout, while it has a direct significant correlation with job performance. Therefore, improving the quality of work life would lead to a reduction in job burnout and an increase in job performance. Furthermore, job burnout had a significant negative effect on job performance. Research has shown that employees usually experience high levels of job burnout (25).

Acar and Erkan, reported a negative significant association between quality of work life and burnout syndrome (26). In a study by Zhang et al. the association between quality of work life and job burnout with job stress were significant (27). It seems that, in order to prevent job stress and job burnout, it is necessary to promote quality of work life.

In Farsi et al.'s study, quality of work life was significantly correlated with the two components of emotional exhaustion and personal accomplishment. However, in the present study, only emotional exhaustion correlated significantly with quality of work life (28). In a study carried out by Ashrafi et al. on nursing, it was revealed that quality of work life has a significant negative association with job burnout, which is consistent with results of the current study (29). Moreover, Karim's findings on prison staff indicated that there was a significant association between job burnout and quality of work life (30). Therefore, it can be said that it is feasible to reduce job burnout among the staff of all occupations through the enhancement of quality of work life. In this study, the components of constitutionalism in the work organization and adequate and fair compensation had a significant negative association with job burnout. On the other hand, Barret and Yates argue that low payment and salary is one of the causes of burnout (31). In addition, Aziznejad and Hosseini referred to low salaries and payment as the main cause of job burnout (32).

There is a strong significant correlation between quality of work life and job performance, which is an indicative of the fact that an increase in quality of work life leads to an increase in employees' job performance. The improvement of quality of work life is essential for the promotion of the organization's performance in such a way that the relation between some dimensions of quality of work life with organizational performance has been proven in the studies conducted by Aketch, et al, (33), Rai et al. (34). The results of the current study is in agreement with those of the study undertaken by Yazdani and Ghasemi on employees of Shiraz Petrochemical Company, where it was shown that quality of work life has a significant association with job performance (35). In addition, the findings of this study regarding the association between quality of work life and job performance is consistent with those of the study carried out by Shahbazi et al., (36). In this study, the components of social integration and cohesiveness, opportunity for continued growth and security, constitutionalism in the work organization, and social relevance of work life were found to have a significant association with staffs' performance, which is in line with the findings of Abasalt's study. Thus, one of the most important steps in improving employees' performance is to increase the quality of their work life. Indeed, a work environment is of high quality if individuals are considered as the main and core members of the organization and if the workplace enjoys indicators such as in-service training, employee participation in decision-making, job security, and fair pay (37). In this study, job burnout was revealed to have a significant negative association with job performance; on the other hand, research findings have shown that job burnout reduces work capacity (38). In this regard, Gandi et al. also argue that job burnout affects job performance (39). Another 
confirming the association between job burnout and job performance is Hosseini et al.'s study, which was conducted on auditors wherein it was revealed that there is a significant negative association between job burnout and job performance (40).

The promotion of quality of work life is essential in improving organizational performance (33) and individuals' job performance, and quality of work life can be improved through an autonomous work redesign, job security, opportunities for growth, administrative and organizational justice, job enrichment and job redesign, suggestions system, employee participation, and flexibility in work schedules (41).

The quality of work life is a comprehensive and inclusive plan that enhances employees' satisfaction, promotes their learning in the environment, and helps them with tasks pertaining to management, change, and transformation. Employees' dissatisfaction with quality of work life is detrimental to all employees, but it is relatively difficult to determine exactly what indicators are correlated with quality of work life (42). However, a study conducted in China shows that all occupational features, including autonomy, support, and feeling of worthiness should be taken into consideration by organizations so that employees will be motivated and get enabled to achieve the goals of the organization (43).

Both job burnout and job performance may also be affected by other factors such as stress and organizational factors, in addition to quality of work life. Therefore, it is suggested that other factors should be considered in this respect for future studies.

Regarding the limitations, it is worth mentioning that, since this research was a cross-sectional study, it only addressed the relationships among factors, not the cause and consequences. Another limitation was related to the fear of disclosing information which, in some cases, could have led the participants to give unreal responses, but the attempts were made to tackle this issue by making the subjects aware of the confidentiality of the research project and the security of the data.

\section{Conclusion}

Quality of work life is significantly correlated with job burnout and job performance. Consequently, it should be noted that each organization needs to have employees who are physically and mentally healthy in order to achieve its goals because occupational burnout significantly affects job performance. Thus, it is possible to reduce job burnout and improve job performance through promoting quality of work life, improvement of salary payment, observance of rules and fairness in dealing with all staff, the provision of a healthy physical and mental environment, promoting employees' job status, encouraging employees to continue education, and job-time adjustment.

\section{Acknowledgement}

We extend our gratitude to all the colleagues at the Vice Chancellor of Research Affairs, the hospitals, and health centers for assisting us in this research project.

\section{Conflict of interest: None declared.}

\section{References}

1. Farsi Z, Nayeri ND, Sajadi A. General health status and burnout of the hematopoietic stem cell transplantation nurses in Tehran. International journal of community based nursing and midwifery. 2013;1(1):52-61.

2. Suner-Soler R, Grau-Martin A, Font-Mayolas $S$, Gras M, Bertran C, Sullman M. Burnout and quality of life among Spanish healthcare personnel. Journal of psychiatric and mental health nursing. 2013;20(4):305-13.

3. Hashemi Dehaghi Z, Sheikhtaheri A. Quality of work life and job satisfaction of nursing managers. Iran J Public Health 2014; 43(4):5378.

4. González-Baltazar R, Hidalgo-Santacruz G, León-Cortés SG, Contreras-Estrada MI, AldreteRodríguez MG, Hidalgo-González BJ, et al. Quality of Work Life and Mental Health in Primary Care Physicians. Procedia Manuf 2015; 3:493540.

5. Argentero P, Miglioretti M, Angilletta C. Quality of work life in a cohort of Italian health workers. $G$ Ital Med Lav Ergon 2007; 29(1 Suppl A):A50-4.

6. Ngambi HC. Can job-sharing improve quality of work life in South Africa? Southern African Business Review 2000; 4(1):1-14.

7. Sirgy MJ, Efraty D, Siegel P, Lee DJ. A New Measure of Quality of Work Life (QWL) Based on Need Satisfaction and Spillover Theories. Soc Indic Res 2001; 55(3):241-302.

8. Hood JN, Smith HL. Quality of work life in home care. The contribution of leaders' personal concern for staff. J Nurs Adm 1994; 24(1):40-7.

9. Farsi Z, Rajaei N, Habibi H. The relationship between burnout and quality of working life in nurses of AJA hospitals in Tehran. Journal of Military Caring Sciences 2015; 1(2):63-72

10. Meyer RM, Li A, Klaristenfeld J, Gold JI. Pediatric novice nurses: examining compassion fatigue as a mediator between stress exposure and compassion satisfaction, burnout, and job satisfaction. J Pediatr Nurs 2015; 30(1):174-83.

11. McCue JD. The effects of stress on physicians and their medical practice. N Engl J Med 1982; 306(8):458-63. 
12. West CP, Huschka MM, Novotny PJ, Sloan JA, Kolars JC, Habermann TM, et al. Association of perceived medical errors with resident distress and empathy: a prospective longitudinal study. JAMA 2006; 296(9):1071-8.

13. Ahola K, Hakanen J, Perhoniemi R, Mutanen P. Relationship between burnout and depressive symptoms: A study using the person-centred approach. Burn Res 2014; 1(1):29-37.

14. Dashti S, Faradmal J, Soheili Zad M, Shahrabadi $R$, Salehiniya $H$. Survey of factors associated with burnout among health care staffs in Hamadan County in year 2012. Pajouhan Scientific Journal 2014;13(1):1-8.

15. Abdul Ghani NM, Muhamad Yunus NSN, Bahry NS. Leader's Personality Traits and Employees Job Performance in Public Sector, Putrajaya. Procedia Economics and Finance 2016; 37:4651.

16. Afzali A, Motahari AA, Hatami-Shirkouhi L. Investigating the influence of perceived organizational support, psychological empowerment and organizational learning on job performance: an empirical investigation. Tehnički vjesnik 2014; 21(3):623-9.

17. Bakker AB, Demerouti E. Towards a model of work engagement. Career Development International 2008; 13(3):209-23.

18. Swansburg RC, Swansburg RJ. Introduction to Management and Leadership for Nurse Managers. 3rd ed. Burlington, Massachusetts, United States: Jones \& Bartlett Learning; 2002.

19. Taris TW. Is there a relationship between burnout and objective performance? A critical review of 16 studies. Work Stress 2006; 20(4):316-34.

20. Zarei E, Ahmadi F, Danshkohan A, Ramezankhani A. The correlation between organizational commitment and the quality of working life among staff of Sarpolzahab health network. Journal of Health Promotion Management 2016; 5(2):61-9.

21. Ghaleei A, Mohajeran B, Taajobi M, Imani B. Relationship between quality of work life and occupational stress in staff of Bu-ali Sina university of Hamadan, 2013. Pajouhan Scientific Journal 2015; 13(4):60-6.

22. Circenis K, Millere I. Compassion Fatigue, Burnout and Contributory Factors among Nurses in Latvia. Procedia Soc Behav Sci 2011; 30:2042-6.

23. Ziaei M, Yarmohammadi H, Karamimatin B, Yarmohammadi S, Nazari Z, Gharagozlou F. Prevalence and risk factors of occupational burnout among nurses of a hospital in Kermanshah in 2013. Iranian Journal of Ergonomics 2014; 2(2):67-74.

24. Ardestani SS, Momeni M, Marjani AB. Investigating of Factors Affecting on Employees' Performance (Case study: National Bank of western branches of Tehran). Paper presented at: The International Conference on Managing
Challenges and Solutions ; 2013 Dec 26; Shiraz, Iran.

25. Grunfeld E, Whelan TJ, Zitzelsberger L, Willan AR, Montesanto B, Evans WK. Cancer care workers in Ontario: prevalence of burnout, job stress and job satisfaction. CMAJ 2000; 163(2):166-9.

26. Acar A, Erkan M. The Effects of Quality of Work Life on Burnout Syndrome: A Study on Hospitality Industry. Journal of Tourismology 2018; 4(1):35-53.

27. Zhang Y, Liu XI, Wei TD, Lan YJ. [Relationship of job stress with job burnout and quality of work life in workers for offshore oil platforms]. Zhonghua Lao Dong Wei Sheng Zhi Ye Bing Za Zhi 2017 ; 35(3):198-202.

28. Farsi Z, Rajaei N, Habibi H. The relationship between burnout and quality of working life in nurses of AJA hospitals in Tehran. Journal of Military Caring Sciences 2015; 1(2):63-72.

29. Ashrafi Z, Ebrahimi H, Khosravi A, Navidian A, Ghajar A. The Relationship Between Quality of Work Life and Burnout: A Linear Regression Structural-Equation Modeling. Health Scope 2018;7(1):e68266.

30. Karimi $H$. Investigating the relationship between job burnout and quality of working life of prison staff in Fars province. Paper presented at: The 2th National Conference on Modern Management Science; 2013 Sep 5; Gorgan, Golestan, Iran.

31. Barrett L, Yates P. Oncology/haematology nurses: a study of job satisfaction, burnout, and intention to leave the specialty. Aust Health Rev 2002; 25(3):109-21.

32. Aziz Nejad P, Hosseini SJ. Occupational burnout and its causes among practicing nurses in hospitals affiliated to Babol University of Medical Sciences, 2004. Journal of Babol University of Medical Sciences 2006; 8(2):63-9.

33. Aketch JR, Odera O, Chepkuto P, Okaka O. Effects of Quality of Work Life on Job Performance: Theoretical Perspectives and Literature Review. Current Research Journal of Social Sciences 2012; 4(5):383-8.

34. Rai R, Tripathi Sh. A Study on QWL and its effects on Job Performance. Journal of Management Scieces and Technology 2015; 2(2):33-42.

35. Yazdani A, Yazdani A, Ghasemi F, Ghalenoei M. The relationship between quality of work life and job performance of employees Shiraz petrochemical operations. Paper presented at: The 1st National Conference on Education and Psychology; 2014 Dec 14; Marvdasht, Fars, Iran.

36. Shahbazi B, Shokrzadeh S, Bejani H, Malekinia E, Ghoroneh D. A survey of relationship between the quality of work life and performance of Department Chairpersons of Esfahan University and Esfahan Medical Science University. Procedia Soc Behav Sci 2011; 30:1555-60.

37. Esmaeeli Lahmali A. A Study of Relationship between Quality of Work Life (QWL) and 
Performance of the Staff in Mazandaran Provin Tax Affairs General Directoratece. Journal of Tax Research 2013; 21(19):171-96.

38. Honkonen $\mathrm{T}$, Ahola K, Pertovaara M, Isometsä E, Kalimo R, Nykyri E, et al. The association between burnout and physical illness in the general population--results from the Finnish Health 2000 Study. J Psychosom Res 2006; 61(1):59-66.

39. Gandi JC, Wai PS, Karick H, Dagona ZK. The role of stress and level of burnout in job performance among nurses. Ment Health Fam Med 2011; 8(3):181-94.

40. Marvian Hosseini Z, Lariye Dashte Bayaz M. Investigation the role of occupational burnout on the relationship between stress and job performance of auditors. Quarterley Journal of Health Accounting 2015; 4(1):57-80.

41. Srivastava S, Kanpur R. A Study on Quality of Work Life: Key Elements \& It's Implications. IOSR Journal of Business and Management 2014; 16(3):54-9.

42. Nasl Saraji G, Dargahi H. Study of Quality of Work Life (QWL). Iranian Journal of Public Health 2006; 35(4):8-14.

43. Chan KW, Wyatt TA. Quality of Work Life: A Study of Employees in Shanghai, China. Asia Pacific Business Review 2007; 13(4):501-17. 